\title{
Chapter 8 \\ How the Implementation of the Landing Obligation Was Weakened
}

\author{
Björn Stockhausen
}

\begin{abstract}
This chapter covers the development of provisions and exemptions to the Landing Obligation in the years following the adoption of the Common Fisheries Policy in December 2013. It focuses on the processes leading to certain changes in Article 15, the development of discard plans, and describes reasons for the slow implementation of the Landing Obligation. It provides further insight into why the intention of the objective of the discard ban, the reduction of unwanted catches, has not yet been achieved to its maximum possible extent.
\end{abstract}

Keywords Data collection · Discard plans · High survival · Implementation · Omnibus Regulation

\subsection{Introduction}

Prior to the reform of the Common Fisheries Policy (CFP), European policy makers were aware of the issue of discarding fish and considered it to wasting a natural resource. The European Commission described ways forward in a green paper (European Commission 2009) and outlined provisions to improve that situation in its final legislative proposal in 2011 (European Commission 2011).

This initial proposal, while it contained already a gradual phasing-in of the new rules per fish stock, was substantially changed by both co-legislators, the European Parliament and the European Council of Ministers (hereafter referred to as "Council"). Amongst those changes were a delayed timeline for the introduction of the new Landing Obligation, a range of exemptions based on scientific evaluations, and the possibility for Member States to jointly propose, on a regional basis, so-called discard plans, comprising details of the implementation of the Landing Obligation for respective sea basins.

A political agreement between the European Parliament, the Council and the Commission was found in May 2013 at the end of the trilogue where all three entities

B. Stockhausen $(\bowtie)$

Seas At Risk, Brussels, Belgium

(C) The Author(s) 2019

S. S. Uhlmann et al. (eds.), The European Landing Obligation, https://doi.org/10.1007/978-3-030-03308-8_8 
negotiated a compromise between their respective positions they had adopted before. After the publication of the basic regulation of the Common Fisheries Policy, the new legal text and its provisions came into force on January 1st, 2014.

However, the political developments and discussions in the following years after the legal text was adopted changed the impact on fisheries management again, and in many cases weakened the positive impact on selectivity and fisheries management a full implementation might have had.

This chapter covers the development of respective provisions in the Landing Obligation (CFP Article 15) in the years following its legal adoption. It focuses on the processes leading to certain changes in Article 15, the development of discard plans and describes reasons for the slow implementation of the Landing Obligation. It provides further insight into why the intention of the objective of the discard ban, the reduction of unwanted catches, has not yet been achieved to the maximum possible extent.

\subsection{The Omnibus Regulation 2013-2015}

One week before Christmas' Eve 2013, and two weeks before the adopted basic regulation of the reformed CFP came into force, the Commission released a proposal for the so-called 'Omnibus regulation' (2013/0436 [COD]).

The reason for this proposal was that the new reformed CFP contained several key objectives and provisions that meant that existing legislation was no longer in line with the new policy framework. In particular, the phasing in of the Landing Obligation from January 1st, 2015 onwards meant that there was not enough time to completely revise other framework legislation containing detailed rules that made the application of the new paradigm regarding discards difficult. This is exemplified by the Commission stating that "legislation is required to remove any legal and practical impediments to implementation on a transitional basis while this new framework is being developed" (European Commission 2013).

In its proposal for the Omnibus regulation, the Commission therefore proposed amendments to Council regulations (EC) No 850/98 ('Technical Measures Regulation), (EC) No 1224/2009 (the 'Control Regulation'), and other associated regulations. Provisions within the Technical Measures Regulation such as the Minimum Landing Size (MLS) and catch composition rules meant challenges for fishers, as they would stand in contradiction to the Landing Obligation that foresaw that over time unwanted catches should be avoided and reduced as far as possible. From a control perspective the implementation of the Landing Obligation would mean a shift from monitoring and controlling of landings to catches, this meant that, amongst others, the respective rules on data recording in the Control Regulation would have to be adapted.

Apart from the content of the proposal, the timing of the adoption of the reformed CFP played a key role. The political process was initially hampered by the fact that the Commission only published its proposal in December 2013, while a political 
agreement between the co-legislators on the reformed CFP had been found in May 2013 and the final agreed text existed since October 2013. Further, despite the approaching entry into force of the first phase of the Landing Obligation by January 1st, 2015, the co-legislators were not able to agree on their position on the Omnibus regulation proposal and subsequently on a joint compromise that would have allowed amending the existing regulations in time, before January 2015.

While the Council agreed on its position regarding the Commission proposal on the Omnibus Regulation in June 2014, the Fisheries Committee of the European Parliament was facing upcoming European Elections in May 2014. The Fisheries Committee would only resume its meetings in July - after the election. This implied that the composition of members of parliament could change and potentially further delay discussions. In January 2014, the report on the legislative file was attributed (European Parliament 2014a) to the Fisheries Committee president who would table a working document. In February (European Parliament 2014b), the Commission was invited to present the proposal, while a foreseen exchange of views on the dossier in March was cancelled (European Parliament 2014c). For the April committee meeting, a hearing (European Parliament 2014d) had been organised as agreed in February to provide insights to members on the Landing Obligation on both technical measures and control aspects.

It was therefore unfortunately not possible for the Fisheries Committee to discuss the proposal further prior to the end of its legislative term and to facilitate and accelerate the legislative procedure towards an earlier adoption in 2014 than ultimately achieved in 2015.

After the European Elections in May 2014, the new members of the Fisheries Committee reconvened in July. A new Chair of the Fisheries Committee was appointed, who continued discussions based on previous agreements. For the July 2014 meeting, a working document had been prepared summarising the presentations and discussion of the April hearing including additional studies by the European Parliament Policy Department B (European Parliament 2014e). As the Fisheries Committee had been partially reshuffled and new members had to become familiar with the file, it took still until December for the Fisheries Committee to adopt its position. It was only in January 2015 that a political agreement with the Council was reached. Following approval by Council and Parliament plenary, the final legislative act came into force in June $2015-6$ months after the Landing Obligation had been introduced for the first fisheries (European Union 2015).

At this point, the content of the Omnibus proposal had changed significantly. What was originally intended as a regulation to align existing legislation with the new CFP and in particular to facilitate the implementation of the Landing Obligation, had in some respects weakened the recently agreed CFP.

Amongst the changes was, for example, an additional exemption to the Landing Obligation. The originally adopted Article 15 of the CFP foresaw exemptions from the Landing Obligation such as for high survivability or for de minimis in case that increases in selectivity are difficult to achieve or to avoid disproportionate costs for handling the previously discarded fish (Rihan et al., this volume). This means that 
as a last resort, when despite other efforts to reduce the amount of unwanted catches such as swaps between Member States and temporal and spatial measures, there still remains a certain quantity of unwanted fish, a de minimis exemption can be granted based on scientific evaluations, to provide for an outlet and allow for the discarding of those fish. Similar for the exemption for high survivability: In case that scientific studies clearly show that certain species survive to a certain extent, the decision maker can grant the exemption for this species from the obligation to land it.

The Omnibus regulation amended the respective paragraph by adding an exemption for "fish which shows damage caused by predators", without specifying details of what damage means or how it would be controlled. This amendment was only inserted after the vote in the European Parliament Fisheries Committee during the trilogue negotiations, which meant there were fewer opportunities to discuss its implications or to decide on required provisions to guarantee the control of the new exemption.

On control and enforcement, the Commission's initial proposal for the Omnibus regulation foresaw that violating the Landing Obligation would constitute a serious infringement under the current Control Regulation (EC) 1224/2009. The proposal was amended by the co-legislators to include a delay of 2 years, meaning that one could violate the rules of the Landing Obligation for 2 additional years during which this would not constitute a serious infringement from the Landing Obligation.

Further, the Commission had proposed to delete the threshold of $50 \mathrm{~kg}$ of species caught and retained on board for compulsory recording in the logbook. This became necessary for the reason that Article 15.1 of the CFP required that all catches of species that are subject to catch limits (or that are subject to minimum sizes in the Mediterranean) "shall be... recorded" and was therefore an essential part of the legal alignment of new and old legislation. Especially, as with the CFP reform, the management shifted from landings to catches, the monitoring and control of all quantities of the latter was fundamental. Nevertheless, Parliament and Council agreed to reinstate the threshold in their political agreement leading to the final adopted text, maintaining a $50 \mathrm{~kg}$ threshold, potentially leaving, if added up across the EU, large quantities of removals unaccounted for.

Lastly, amendments were introduced by the Parliament which required the Commission to annually report on the implementation of the Landing Obligation, based on information provided from Member States and Advisory Councils from 2016 onwards. These reporting requirements were subsequently specified by the Scientific, Technical and Economic Committee for Fisheries, STECF (STECF 2016b; see Rihan et al., this volume). These reports have provided useful insight into the process and progress of the implementation of the Landing Obligation.

In summary, despite the pressing timeframe, the co-legislators did not manage to adopt the required legal changes in the Omnibus Regulation before the first phase of the Landing Obligation came into force in January 2015. Further, the Omnibus Regulation introduced amendments to the recently reformed CFP and to some key aspects of the Landing Obligation which weakened the overarching policy that was agreed only 18 months earlier. 
In summary, one of the elements that weakened the Landing Obligation policy was the Omnibus regulation (EU 2015/812) which was supposed to legally align existing legislation such as the 'Fisheries Control Regulation' (EC 1224/2009) or the 'Technical Measures Regulation' (EC 850/98). It weakened the recently reformed basic regulation of the CFP by adding additional exemptions to the Landing Obligation in Article 15.

\subsection{High Survival - A Concept Undefined by Decision Makers}

Amongst the exemptions from the Landing Obligation was Article 15.4(b), stating that the Landing Obligation shall not apply to "species for which scientific evidence demonstrates high survival rates, taking into account the characteristics of the gear, of the fishing practices and of the ecosystem".

Unfortunately, the term 'high survival' was not further described or clarified by the co-legislators in the whole legislative document. The exemption was introduced by both the Parliament and the Council in their report (European Parliament 2013) and general approach (Council of the European Union 2013), respectively. Following the political agreement on the reformed CFP, the STECF was asked in September 2013 for scientific support, and the request by the European Commission already mentioned that "There is currently no objective means to define high survival rates". The STECF was asked to (i) develop guidelines or identification of best practice for undertaking discard survival studies, (ii) develop an objective framework to define high survival which will provide managers with a range of the likely impacts of different options depending on the definition used; (iii) assess the impacts if a proportion of the landed catch that would have been discarded might otherwise have survived and how this may affect estimates of fishing mortality, spawning stock biomass (SSB) and associated reference points; and (iv) if possible define a predefined list of species and fisheries that could be considered for exemption on the basis of high survival (STECF 2013).

Following this initial request, a series of STECF meetings provided recommendations on the different requests. Already the first report of the September 2013 meeting, the STECF Expert Working Group EWG 13-16, stated "that the term 'high survival' is somewhat subjective", and that "defining a single value [of survival] cannot be scientifically rationalised and therefore EWG 13-16 advises that assessing proposed exemptions on the basis of 'high survival' need to be considered on a caseby-case basis taking [into] account the specificities of the species and fisheries involved". This important remark was re-iterated in the following years by stating that "without clear definitions of the terms, [...] 'high survival', there are no objective scientific criteria to judge whether any proposed exemptions from the Landing Obligation are merited." The STECF therefore assessed the scientific 
basis for the different exemptions requested, but referred the judgement "whether such proposals are merited using relevant subjective criteria" back to the decisionmakers, in this case the European Commission - as being responsible for adopting specific discard plans through delegated acts (Rihan et al., this volume).

Over subsequent years the STECF provided much needed clarity and scientific support to facilitate the implementation of the Landing Obligation. For example, apart from developing guidelines for survivability studies, the STECF EWG 13-17 recommended guidelines for the regional discard management plans "where an exemption under high survival is being proposed". In relation to high survival exemptions, the EWG recommended specific information that should be included, e.g. species name, respected stock(s) and management unit, descriptions of gear types used, catch composition and other operational characteristics, the discard profile, selectivity measures developed and effects of the Landing Obligation on the stocks (STECF 2014a, b).

Nevertheless, when the STECF was requested to evaluate Joint Recommendations submitted to the Commission by respective regional Member States groups in the following years, these recommendations seem not to have been taken on board by Member States.

The STECF in 2015 reports of "inconsistencies in the definition of the fleets", "it is unclear ... to which fleets such de minimis volumes will be accessible" or that exemptions "appear to be intended to cover residual discards and as such essentially equate to "business as usual" (STECF 2015b). In many cases, additional supporting information had to be requested from Member States after the submission of the Joint Recommendations to improve the justification provided. Still, the STECF noted in several cases that the additional information provided referred only to single Member States rather than corresponding to the fishery for which the exemption was requested.

This situation continued in 2016 when the STECF identified "a number of general issues and limitations" in the Joint Recommendations (STECF 2016a). Even after additional responses were received from Member States and regional groups, information was often insufficient or lacking. "None of the JR [Joint Recommendations] received contain any concrete measures for the documentation of catches", which was a violation of the requirements of Article 15.1 CFP (see previous part of this chapter).

Since 2015, discard plans have been adopted for all major sea basins of the European Union, i.e., the Baltic Sea, the North Sea, North- and South-Western Waters, the Mediterranean and the Black Sea. By 2017, Joint Recommendations had generally improved, but still contained "limitations in the information provided" and "often information is provided for one fleet but not for other fleets using similar gears and which would be also affected", as noted by the STECF (STECF 2017b). The number of species and fisheries included in the discard plans and therefore subject to the Landing Obligation, has increased only slowly. Until June 2017, from a total number 174 stocks subject to the Landing Obligation, there were still 77 stocks not covered at all while 97 were either fully or partially included in discard plans. 
The legal wording adopted by policy makers on the Landing Obligation put a lot of burden on the STECF that was requested to evaluate the Joint Recommendations submitted by regional Member State groups (Rihan et al., this volume). The STECF had, from the very beginning, provided guidelines on the information necessary to conduct a satisfactory evaluation, which provided Member States with the tools and information for a gradual implementation. Despite the ambitious timeframe, Member States could have coordinated data collection in a better way than eventually happened, especially as every year the STECF provided information on where information was missing and how the justifications should be improved which could have been used for the JR of the next year. Regarding the justification provided, the Commission had to send throughout the years additional requests to Members States after receiving the respective Joint Recommendations, and even in these cases, Member States did not always provide sufficient information. Finally, the number of stocks introduced to the discards plans was increased only at a slow pace, which will mean that in the final year of the implementation of the Landing Obligation, in 2019, a large number of remaining stocks still have to be implemented into the Landing Obligation through the respective discard plans.

In summary, the adopted wording in Article 15 of the Common Fisheries Policy regarding 'high survival' had not been defined in the legal text. As it is an important threshold for whether or not a species can be exempted from the Landing Obligation, its application had to be discussed. This section reviewed how this was clarified by respective scientific bodies, highlighting how these became even more entangled in the political process.

\subsection{The Drafting of Discard Plans}

Article 15.6 of the CFP foresees that so-called discard plans containing the specifications for the Landing Obligation in a specific sea basin shall be adopted through delegated acts by the European Commission, following the legislative procedure outlined in Article 18 of the CFP. Article 18 foresees that in line with the regionalisation concept, Member States with a direct management interest can submit Joint Recommendations to achieve the respective objective of the conservation measure, in this case the Landing Obligation.

In this context, groups of Member States have submitted since 2014 so-called Joint Recommendations for the respective sea basins, outlining amongst others the fisheries to include in the discard plans, closures, and their requests for exemptions from the Landing Obligation and including evidence to justify these exemptions.

As the quality of the justifications provided should be used by the European Commission to determine whether exemptions are granted subsequently, it should be obvious that Member States apply their greatest efforts to provide complete information based on the best available scientific advice, and that subsequently the 
European Commission executes the greatest scrutiny when deciding on whether to grant exemptions (or not) to ensure that the corresponding objective of the CFP, the avoidance and reduction of unwanted catches, is not unnecessarily and unjustifiably weakened. Member States also should have a strong interest in providing wellfounded Joint Recommendations because the requested exemptions ultimately lead to facilitating the implementation of the Landing Obligation for their fleets and fishers.

As outlined above, these joint recommendations are evaluated by the STECF by scrutinising the supporting information and providing corresponding recommendations to the European Commission (Rihan et al., this volume). And as documented in several STECF reports, the underlying data and studies provided were often insufficient for various reasons (e.g., limited research funding for a well-replicated study). The question to ask is whether the European Commission has followed the scientific recommendations. For example, in cases where the STECF indicated that the justification provided for certain exemptions had been insufficient, why did the European Commission adopt the discard plans including the respective exemption?

As outlined in the previous section, in several cases the initial information provided by Member States was insufficient and the Commission had to request additional information after the meeting of the respective Expert Working Group, putting additional burden on the subsequent STECF plenary meeting. In addition to that, less time could be spent analysing the new information, compared to a dedicated stand-alone EWG.

It was also clear that the timing of the subsequent scientific evaluation and legislative process required an early submission of the Joint Recommendations to allow for the discard plans to come into force on January 1st of the following year. The submission date had been established by the European Commission to be the end of May every year for the Joint Recommendations of the following year to allow for sufficient time for both processes. This date was also often not respected and additional information was sent to the EWG only days before, or in some cases even during the meeting itself, which further impeded the necessary analysis. Therefore, it would have been completely justified to not give Member States the additional possibility to provide information after the deadline or after the EWG meeting. Even in 2017, three years after the process of providing supporting information to justify exemptions had initiated and despite guidelines and templates provided by the STECF, the European Commission still found it necessary to request additional information from Member States.

Additionally, the final adopted legislative act for a discard plan often granted Member States the possibility to provide information until May of the following year to be analysed by the STECF at the following July plenary meeting. See for example the 2016 discard plans with respect to certain fisheries of hake in south-western waters (European Commission 2015a) and whiting in north-western waters (European Commission 2015b); the 2017 discard plans with respect to certain fisheries of hake in south-western waters (European Commission 2016a) and sole 
in north-western waters (European Commission 2016b), and the 2018 discard plans with respect to certain fisheries of sole in north-western waters (European Commission 2018).

Looking into one of these examples in detail, it is important to note that for hake in south-western waters, additional information was requested twice in subsequent years and that both requests were for the same fisheries. The report of the STECF expert group in 2015 stated that that no relevant information as well as limited and non-quantitative information were presented (STECF 2015b). The following STECF plenary (STECF 2015a) meeting in July 2015 analysed additional information provided by the respective Member States upon request of the European Commission following the process described above, and the report still stated that the additional supporting information is still "rather generic" and that "further selectivity studies should be carried out". Nevertheless, the adopted discard plan for 2016 granted the exemption including the obligation to provide additional information. In 2016, the next STECF expert group (STECF 2016a) was requested to evaluate whether the required additional information was provided. The STECF concluded that the information provided related to only one Member State involved in the fishery and that no specific information for other Member State fleets was provided that were (in 2016) and would be (in 2017) subject to an exemption. The report continued stating that unclear catch information was supplied and that the Joint Recommendation was missing the level of de minimis. The report concludes that "it is still not currently possible to evaluate whether the arguments of disproportionate costs are well founded". Again, the subsequent STECF summer plenary had to evaluate the additional information provided by Member States upon request by the European Commission, and the report again stated that little additional information was provided and that additional selectivity information provided does not contain any additional evidence. In the same procedure as the previous year, the exemption was granted in the discard plan for 2017 as outlined above, with the requirement to provide additional supporting information.

This means, that by the end of 2017 , for 2 years, a fishery had been granted an exemption, despite repeated scientific analysis stated each time that inconsistencies and insufficient information prevailed, and despite that respective Member States had multiple chances to provide the missing information.

In hindsight, this example shows that the European Commission could have applied stricter scrutiny regarding the requirements for Member States to provide information that supported exemptions. Exemptions should have been adopted only when the required information was complete. The multiple STECF evaluations resulting from subsequent weakly supported exemptions not only placed an extra burden on the STECF, but might have given the impression to Member States that no serious efforts are necessary to obtain exemptions from the Landing Obligation.

In summary, the Commission seems not to have followed the evaluation by the STECF when transposing the JRs into discard plans, because justifications were often incomplete or information was not provided - despite additional requests or the possibility to provide information until the following year. 


\subsection{Data Collection and Reporting Requirements Under the Landing Obligation}

The CFP states in Recital 46 that "Fisheries management based on the best available scientific advice requires harmonised, reliable and accurate data sets" and that Member States should collect data on discards under exemptions. With regard to the Landing Obligation, this is further specified in Article 15.1 that requires that all catches of species which are subject to catch limits (or that are subject to minimum sizes in the Mediterranean) "shall be ... recorded". With regard to de minimis exemptions, it is further specified in Article 15.5(c) (ii) that even though these catches "shall not be counted against the relevant quotas; however, all such catches shall be fully recorded".

This shows that the co-legislators were fully aware of the importance of a comprehensive data collection system to provide the respective scientific entities such as the STECF and ICES with the best available data for scientific evaluation. The corresponding provisions to outline the data collection provisions, also referred in Article 15.5.d ("provisions on documentation of catches") were supposed to be included in multiannual plans or, where these were not adopted, in discard plans, as specified in Article 15.6.

As outlined previously, quite a number of discard plans have been adopted and amended since the phasing in of the Landing Obligation in 2015 (19 as of May 2018) - with no provisions for collecting and recording data. The Joint Recommendations submitted by regional groups of Member States to the European Commission have been thoroughly analysed by respective STECF expert groups and plenary meetings. Before the phasing in of the Landing Obligation, the STECF reported "From a control perspective, the fact that catches discarded under the de minimis provisions do not count against quota, creates a significant risk of non-compliance around de minimis" (STECF 2014b). Therefore, stronger legal requirements to fully record these catches would have been important, especially as the previously discarded amounts of fish are added as additional quota (so-called "top-ups") while deducting the de minimis amounts.

Looking at the analyses done by the STECF, this seems not to have been the case. The STECF recognised early in the process, in 2014, in one of the first Mediterranean Joint Recommendations, that while a rationale to collect data was mentioned, the document lacked indication how the data will be collected. In 2015, the assigned STECF EWG reported a general lack of relevant data associated for fleets and vessels falling under the Landing Obligation, "which is necessary to estimate of their relative contribution to the overall catches of the stocks concerned and the potential volumes of de minimis catches that may be attributed/allocated to them". The STECF added that "that no specific provisions have been included in the JR's [Joint Recommendations]" for the recording of de minimis catches and discards. In 2016, the STECF EWG reiterated the missing respective provisions in Joint Recommendations regarding the requirement to fully record de minimis catches 
following Article 15.5 (c) (ii) of the CFP (STECF 2016a), as did likewise the respective STECF EWG in 2017 (STECF 2017b). In addition, the 2017 STECF spring plenary notes that "Member States also indicate a lack of reporting by vessel operators of fish discarded under exemptions (i.e., de minimis and high survivability), discards of fish currently not subject to the Landing Obligation and catches of fish below MCRS" (STECF 2017a), which is iterated in 2018, adding the remark that "Based on the Member States reports, the quantities of discards and unwanted catches being recorded in logbooks are extremely low and do not match information from observer trips or from last observed haul analyses carried out by inspectors. Inaccurate or incomplete catch data will compromise the provision of scientific advice" (STECF 2018).

The consistency outlined in these reports regarding the monitoring requirement agreed to in the 2013 CFP reform shows that the implementation of the Landing Obligation has been suffering from a fundamental disrespect and mis-understanding for the importance of this key aspect. Despite the continuous and annual remarks by the respective scientific bodies, Member States seem to not have taken the requirement seriously, potentially because it might have shown that actual improvements in selectivity have not been implemented or achieved to the point necessary to facilitate the full implementation of the Landing Obligation. Better data collection is of utmost importance during this time of changing policies to accompany the political process. Also, the scientific assessments during this period have potentially suffered. The new CFP with its paradigm shift from requiring to land previously discarded fish, requires adjusting data collection to have the best available scientific knowledge on how many fish area actually returned to sea.

In summary, the change in the policy objective from the requirement to discard unwanted catches to the obligation to avoid and reduce as far as possible unwanted catches also came with the requirement to monitor and record the respective amounts of catches, both for legal and for stock assessment reasons.

Acknowledgments Disclaimer: The views and opinions expressed in this chapter are those of the author and do not reflect the official position of any employer.

\section{References}

Council of the European Union. (2013). Revised general approach on the proposal for a regulation of the European Parliament and of the Council on the Common Fisheries Policy. 6108/1/13 REV1 http://register.consilium.europa.eu/doc/srv?l=EN\&f=ST\%206108\%202013\%20REV\% 201. Accessed 27 August 2018.

European Commission. (2009). Green paper on the reform of the common fisheries policy. COM (2009)163 final. https://eur-lex.europa.eu/LexUriServ/LexUriServ.do?uri=COM:2009:0163: FIN:EN:PDF. Accessed 27 August 2018.

European Commission. (2011). Proposal for a regulation of the European Parliament and of the Council on the common fisheries policy. COM(2011) 425 final. https://eur-lex.europa.eu/legalcontent/EN/TXT/PDF/?uri=CELEX:52011PC0425\&from=EN. Accessed 27 August 2018. 
European Commission. (2013). Proposal for a REGULATION OF THE EUROPEAN PARLIAMENT AND OF THE COUNCIL amending Council Regulations (EC) No 850/98, (EC) No 2187/2005, (EC) No 1967/2006, (EC) No 1098/2007, No 254/2002, (EC) No 2347/2002 and (EC) No 1224/2009 and repealing (EC) No 1434/98 as regards the landing obligation. https:// eur-lex.europa.eu/resource.html?uri=cellar:017cc877-67c5-11e3-a7e4-01aa75ed71a1.0004. 01/DOC_1\&format=PDF. Accessed 27 August 2018.

European Commission. (2015a). Commission Delegated Regulation (EU) 2015/2439 of 12 October 2015 establishing a discard plan for certain demersal fisheries in south-western waters. https:// eur-lex.europa.eu/legal-content/EN/TXT/PDF/?uri=CELEX:32015R2439\&from=EN.

Accessed 27 August 2018.

European Commission. (2015b). Commission Delegated Regulation (EU) 2015/2438 of 12 October 2015 establishing a discard plan for certain demersal fisheries in north-western waters. https:// eur-lex.europa.eu/legal-content/EN/TXT/PDF/?uri=CELEX:32015R2438\&from=EN. Accessed 27 August 2018.

European Commission. (2016a). Commission Delegated Regulation (EU) 2016/2374 of 12 October 2016 establishing a discard plan for certain demersal fisheries in South-Western waters. https:// eur-lex.europa.eu/legal-content/EN/TXT/PDF/?uri=CELEX:32016R2374\&from=EN. Accessed 27 August 2018.

European Commission. (2016b). Commission Delegated Regulation (EU) 2016/2375 of 12 October 2016 establishing a discard plan for certain demersal fisheries in North-Western waters. https:// eur-lex.europa.eu/legal-content/EN/TXT/PDF/?uri=CELEX:32016R2375\&from=EN.

Accessed 27 August 2018.

European Commission. (2018). Commission Delegated Regulation (EU) 2018/46 of 20 October 2017 establishing a discard plan for certain demersal and deep sea fisheries in North-Western waters for the year 2018. https://eur-lex.europa.eu/legal-content/EN/TXT/PDF/? uri $=$ CELEX:32018R0046\&from $=$ EN. Accessed 27 August 2018.

European Parliament. (2013) European Parliament legislative resolution of 6 February 2013 on the proposal for a regulation of the European Parliament and of the Council on the Common Fisheries Policy (COM(2011)0425 - C7-0198/2011 - 2011/0195(COD)). P7_TA(2013)0040. http://www.europarl.europa.eu/sides/getDoc.do?pubRef=-//EP//NONSGML+TA+P7-TA2013-0040+0+DOC+PDF+V0//EN. Accessed 27 August 2018.

European Parliament. (2014a). European Parliament Fisheries Committee January 2014, minutes. PECH_PV(2014)0122_1. http://www.europarl.europa.eu/meetdocs/2009_2014/documents/ pech/pv/1015/1015544/1015544en.pdf. Accessed 27 August 2018.

European Parliament. (2014b). European Parliament Fisheries Committee February 2014, draft agenda. PECH(2014)0211_2. http://www.europarl.europa.eu/meetdocs/2009_2014/documents/ pech/oj/1017/1017048/1017048en.pdf. Accessed 27 August 2018.

European Parliament. (2014c). European Parliament Fisheries Committee March 2014, minutes. PECH_PV(2014)0318_1 http://www.europarl.europa.eu/meetdocs/2009_2014/documents/ pech/pv/1023/1023382/1023382en.pdf. Accessed 27 August 2018.

European Parliament. (2014d). European Parliament Fisheries Committee. Hearing on 7 April 2014 on "Implementing the discard ban". http://www.europarl.europa.eu/committees/en/pech/eventshearings.html?id=20140331CHE82053. Accessed 27 August 2018.

European Parliament. (2014e). European Parliament Fisheries Committee working document on the Committee hearing "Implementing the discard ban". PE536.149v01-00. http://www.europarl. europa.eu/sides/getDoc.do?pubRef=-\%2f\%2fEP\%2f\%2fNONSGML $\% 2 \mathrm{bCOMPARL} \% 2 \mathrm{bPE}-$ $536.149 \% 2 \mathrm{~b} 01 \% 2 \mathrm{bDOC} \% 2 \mathrm{bPDF} \% 2 \mathrm{bV0} \% 2 \mathrm{f} \% 2 \mathrm{fEN}$. Accessed 27 August 2018.

European Union. (2015). Regulation (EU) 2015/812 of the European Parliament and of the Council of 20 May 2015 amending Council Regulations (EC) No 850/98, (EC) No 2187/2005, (EC) No $1967 / 2006$, (EC) No 1098/2007, (EC) No 254/2002, (EC) No 2347/2002 and (EC) No 1224/ 2009, and Regulations (EU) No 1379/2013 and (EU) No 1380/2013 of the European Parliament and of the Council, as regards the landing obligation, and repealing Council Regulation (EC) No 
1434/98. OJ L133, 29.5.2015. https://eur-lex.europa.eu/legal-content/EN/TXT/PDF/? uri=CELEX:32015R0812\&from $=$ EN. Accessed 27 August 2018.

Rihan, D., Uhlmann, S.S., Ulrich, C., Breen, M., Catchpole, T. (this volume). Requirements for documentation, data collection and scientific evaluations. In S.S. Uhlmann, C. Ulrich, S.J. Kennelly (Eds.), The European Landing Obligation - Reducing discards in complex, multi-species and multi-jurisdictional fisheries. Cham: Springer.

STECF. (2013). STECF EXPERT WORKING GROUP EWG 13-16 on a Landing Obligation in EU Fisheries, Terms of Reference. https://stecf.jrc.ec.europa.eu/c/document_library/get_file? uuid $=\mathrm{f} 222 \mathrm{e} 1 \mathrm{e} 5-2 \mathrm{f} 0 \mathrm{c}-420 \mathrm{~b}-9 \mathrm{adb}-2 \mathrm{fa} 6 \mathrm{c} 25814 \mathrm{df} \&$ groupId=43805. Accessed 27 August 2018.

STECF. (2014a). Scientific, Technical and Economic Committee for Fisheries (STECF) - Landing Obligation in EU Fisheries - part II (STECF-14-01). 2014. Publications Office of the European Union, Luxembourg, EUR 26551 EN, JRC 88869, 67 pp. https://stecf.jrc.ec.europa.eu/docu ments/43805/633247/STECF+14-01++Landing+obligations+in+EU+fisheries+-+p2.pdf. Accessed 27 August 2018.

STECF. (2014b). Scientific, Technical and Economic Committee for Fisheries (STECF) - 46th Plenary Meeting Report (PLEN-14-02). 2014. Publications Office of the European Union, Luxembourg, EUR 26810 EN, JRC 91540, 117 pp. https://stecf.jrc.ec.europa.eu/documents/ 43805/812327/STECF+PLEN+14-02.pdf. Accessed 27 August 2018.

STECF. (2015a). Scientific, Technical and Economic Committee for Fisheries (STECF) - 49th Plenary meeting Report (PLEN-15-02).2015. Publications Office of the European Union, Luxembourg, EUR 27404EN, JRC 97003, 127 pp. https://stecf.jrc.ec.europa.eu/c/document_ library/get_file?uuid=78be1880-f78e-446b-895b-41d4bca7dd8c\&groupId=43805. Accessed 27 August 2018.

STECF. (2015b). Scientific, Technical and Economic Committee for Fisheries (STECF) - Landing Obligation - Part 5 (demersal species for NWW, SWW and North Sea) (STECF-15-10)2015. Publications Office of the European Union, Luxembourg, EUR 27407 EN, JRC 96949, 62 pp. https://stecf.jrc.ec.europa.eu/documents/43805/999871/STECF+15-10+-+Landing+obligations +-+p5.pdf. Accessed 27 August 2018.

STECF. (2016a). Scientific, Technical and Economic Committee for Fisheries (STECF) - Evaluation of the landing obligation joint recommendations (STECF-16-10); Publications Office of the European Union, Luxembourg; EUR 27758 EN. https://doi.org/10.2788/59074. https:// stecf.jrc.ec.europa.eu/documents/43805/1471816/STECF+16-10+-+Evaluation+of+LO+joint +recommendations.pdf. Accessed 27 August 2018.

STECF. (2016b). Scientific, Technical and Economic Committee for Fisheries (STECF) - Methodology and data requirements for reporting on the Landing Obligation (STECF-16-13). 2016. Publications Office of the European Union, Luxembourg, EUR 27758 EN. https://doi.org/10. 2788/984496. https://stecf.jrc.ec.europa.eu/documents/43805/1399955/STECF+16-13++Methods+and+data+requirements+for+LO.pdf. Accessed 27 August 2018.

STECF. (2017a). Scientific, Technical and Economic Committee for Fisheries (STECF) - 54th Plenary Meeting Report (PLEN-17-01); Publications Office of the European Union, Luxembourg; EUR 28569 EN. 10.2760/33472. https://stecf.jrc.ec.europa.eu/documents/43805/ 1672821/STECF+PLEN+17-01.pdf. Accessed 27 August 2018.

STECF. (2017b). Scientific, Technical and Economic Committee for Fisheries (STECF) - Evaluation of the landing obligation joint recommendations (STECF-17-08). Publications Office of the European Union, Luxembourg, 2017. ISBN: 978-92-79-67480-8. doi:10.2760/149272, JRC107574. https://stecf.jrc.ec.europa.eu/documents/43805/1710831/STECF+17-08+-+Evalu ation+of+LO+joint+recommendations.pdf. Accessed 27 August 2018.

STECF. (2018). Scientific, Technical and Economic Committee for Fisheries (STECF) - 57th Plenary Meeting Report (PLEN-18-01), Publications Office of the European Union, Luxembourg, 2018. ISBN: 978-92-79-85804-8. doi:10.2760/088784, JRC111800. https://stecf.jrc.ec. europa.eu/c/document_library/get_file?uuid=91be62f0-3aa7-4151-8a0c-b595444a8458\& groupId=43805. Accessed 27 August 2018. 
Open Access This chapter is licensed under the terms of the Creative Commons Attribution 4.0 International License (http://creativecommons.org/licenses/by/4.0/), which permits use, sharing, adaptation, distribution and reproduction in any medium or format, as long as you give appropriate credit to the original author(s) and the source, provide a link to the Creative Commons license and indicate if changes were made.

The images or other third party material in this chapter are included in the chapter's Creative Commons license, unless indicated otherwise in a credit line to the material. If material is not included in the chapter's Creative Commons license and your intended use is not permitted by statutory regulation or exceeds the permitted use, you will need to obtain permission directly from the copyright holder. 